\title{
INFLUENCE OF THE CEMENT DUST ON ANTS GROUPING (HYMENOPTERA, FORMICIDAE)
}

\author{
Tetiana Mykytyn, Nelia Dolynko, Vasyl Stefurak, Natalia Bielova, Vasyl \\ KUZENKO
}

\begin{abstract}
Research of the influence of cement dust in zone of PJSC "Ivano-Frankivskcement" on the ants grouping was conducted. In this exploration was noticed that at the anthropogenic load disappears ants of the genus Formica, which are replaced by species of the genus Lasius and Myrmica.

Analyzing the distribution of ants genera and species on experimental meadows, we found a direct correlation between the ants number and distance from the sources of cement dust ( $\mathrm{r}=0.87$ at $\mathrm{p}<0.05)$. The largest number of the ant species observed in the area of influence from the genus Lasius. Myrmica nests are found not closer than $1 \mathrm{~km}$ from PJSC "Ivano-Frankivskcement", Formica nests are only in the control. Under the action of cement dust on biotopes, the ants display a non-adaptive reaction. The analysis of changes in the population density of the particular genera showed that the nests density of all genera is minimal on the meadows located near the sources of cement dust. With remoteness from the source of pollution, the density of colonies reliably increases $(\mathrm{r}=0,97$ at $\mathrm{p}<0,05)$. Colonies of the genus Formica ( $F$. fusca) registered only in control reached the density of grouping 1,5 $\pm 1,1$ nests at $100 \mathrm{~m}$ the accounting route. For the forest biotopes, the nests density of the genus Lasius is higher in control by 1.8 times $\left(3.1\right.$ nests $\left./ 25 \mathrm{~m}^{2}\right)$ than in the village $\left(1.75\right.$ nests $\left./ 25 \mathrm{~m}^{2}\right)$. For other genera (Camponotus, Myrmica and Formica), an opposite reaction was registered. The nests density of $F$. fusca, which are registered only in the control, reached $2.5 \pm 1.1$ nests for $100 \mathrm{~m}$ the accounting route.

With a decrease in the pollution degree, the proportion of underground nests increases $(r=0,90$ at $p<0,05)$, the proportion of the dome nests decreases $(r=-0,94$ at $p<0,05)$. At the same time, the size of dome on average decreases when removed from the source pollution. All nests registered in the most polluted zone consist of a mixture of cement dust and earths up to $45 \mathrm{~cm}$ high. About $75 \%$ of all nests found were heavily overgrown. When excavating the nests the dome was as if cemented. Adaptation of the ants to the influence of cement dust differs from other influence types and is expressed in the fact that in technogenic territories nests are more often dome-shaped, smaller diameter and considerably higher nests than those located in the control zone. This is because the soil near PJSC "Ivano-Frankivskcement" is covered with a layer of the lime dust which reaches 5 $\mathrm{cm}$.

Lasius niger is resistant to various forms of the anthropogenic influence, which can be explained by the adaptive features of the forms ant nest.
\end{abstract}

Keywords: ants, anthropogenic influence, cement dust, Lasius, Myrmica. 


\section{INTRODUCTION}

Recently, the question of the impact of various types of pollution on fauna and flora has become increasingly acute. Anthropogenic factor, in most cases, has an indirect effect on animals, destroying their habitats, trophic regime, interrupting the channels of intra-population and biocoenotic information [13]. Lack of response to human exposure in herpetobionts is rare. In most cases, industrial emissions affect the impoverishment of insect fauna not only by reducing their species composition $[8,11,12]$, but also by reducing the number of dominant species [4].

Given that in many biogeocenoses among insects of the upper soil layer are dominated by insectszoophagous, and from them - ants [5,7], it is clear the importance of studying the responses of members of the family Formicidae to various forms of anthropogenic impact. Currently, such reactions of ants have not been studied enough.

Industrial pollution, according to the observations of Petal [14], leads to limiting the number of species, reducing the density of nests and the number of individuals in them. In areas of industrial pollution, there are changes in the spatial structure of ant populations, an increase in the proportion of larvae and pupae in families, a decrease in workers body weight [15]; accumulation of copper, lead, cadmium, zinc, fluorine in the ants body [13, 17].

Changes in the species composition and number of ants are also observed with the strengthening of the recreational press. Studies of urban forest parks have shown that with a low recreational load 32\% of the number of detected species of ants in forest parks, with moderate - $88 \%$, with strong - 52\% [1]. The average density of nests of the same species in the city is several times higher than in the forestpark suburban area [16]. Only Myrmica rubra and Lasius niger can be found in areas with different degrees of recreational load $[1,5]$. These are the species that, according to some authors $[5,9]$, are the most resistant to any type of anthropogenic impact. Great resistance to recreational load is generally shown by species of the genus Myrmica, however, at high load the density of nests and the frequency of M. rubra decreases [5, 9]. At the same time, according to the observations K. Uspensky [10, p. 12], the highest density of ant nests of M. rubra is observed in the area with a strong recreational load.

We conducted research in connection with contradictory information and not studied the anthropogenic impact in the Ivano-Frankivsk region.

\section{MATERials AND Methods OF RESEARCH}

Studies of the impact of cement dust on myrmecocomplexes were conducted in the village Yamnytsia, Tysmenytsia district, Ivano-Frankivsk region and its environs, near the cement plant of PJSC "Ivano-Frankivskcement".

The collection of material and its in-house processing was carried out according to traditional methods and techniques. Ants were selected by hand, with entomological tweezers, and soil traps were laid. To quantify the species composition of ants of the genus Formica used the methods of $\mathrm{K}$. Arnoldi. The counting of nests and sampling of ants was performed according to the method of G. Dlusky [3]. Anthills were described by standard methods. Accounting for construction material was performed visually, the material was not selected.

Zones of influence of industrial enterprises on the territory of cities are allocated according to works of N. Demidenko, T. Skala and L. Kovrigina, N. Fomina. Based on these data, it can be argued that the greatest pollution from solid emissions occurs at a distance of up to $600-700 \mathrm{~m}$ from the emission source, and at a distance of $1.5 \mathrm{~km}$ the impact on soil mesofauna is reduced by half.

Statistical processing used the software package Statistica 7 and Excel 2007 [3] and statistical methods [6, p. 19].

Grass meadows and deciduous forests located at different distances from the source of cement dust were studied: within the village and $30 \mathrm{~km}$ from the village border (control).

Research sites:

1 - meadows - 48 $58^{\prime} 32.1^{\prime \prime} \mathrm{N} 24^{\circ} 42^{\prime} 32.1^{\prime \prime} \mathrm{E}$; 
2 - meadows control - 49 ${ }^{\circ} 13^{\prime} 17.3^{\prime \prime} \mathrm{N} 24^{\circ} 43^{\prime} 40.2^{\prime \prime} \mathrm{E}$;

3 - forest - 48 $58^{\prime} 09.9^{\prime \prime} \mathrm{N} 24^{\circ} 42^{\prime} 46.4^{\prime \prime} \mathrm{E}$;

4 - forest control $-49^{\circ} 14^{\prime} 34.5^{\prime \prime} \mathrm{N} 24^{\circ} 44^{\prime} 57.2^{\prime \prime} \mathrm{E}$.

\section{RESEARCH RESULTS AND THEIR DISCUSSION}

\subsection{TAXONOMIC AND SPECIES COMPOSITION OF ANTS IN THE STUDY AREA}

Total in the research area villige Yamnytsia, and its environs, found 8 species of ants belonging to 4 genera, 2 subfamilies (Fig. 1).

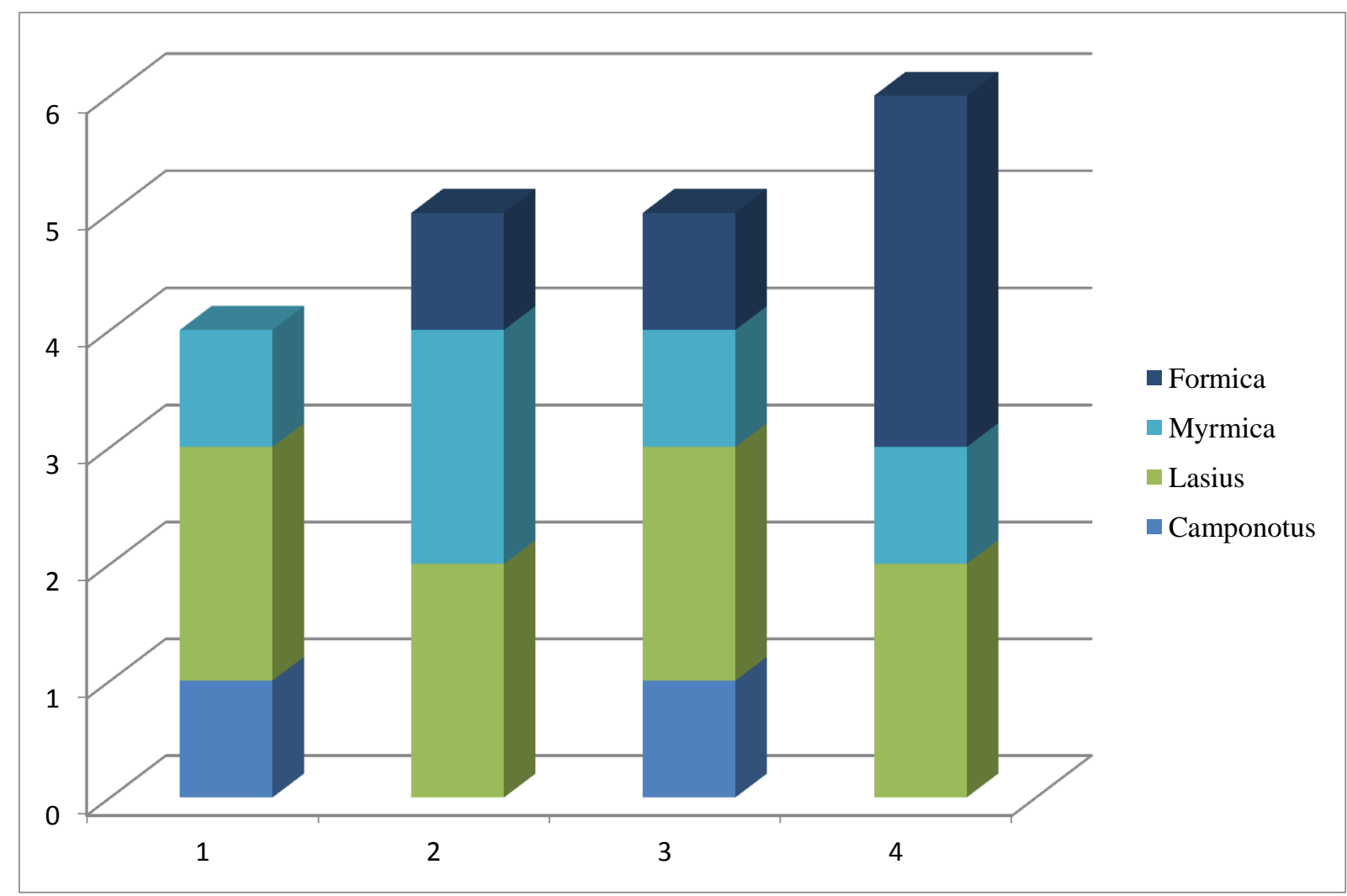

Fig. 1. Species richness of ants in the research territory in the area of influence of the cement industry. On the X axis the research area: 1 - meadows in the village, 2 -control for grass meadows; 3 -forest; 4 -control for the forest; along the $B$ axis - the number of species.

Most species belong to the subfamily Formicinae (6 species, 75\%). Representatives of the subfamily Myrmicinae account for 25\% (2 species). A direct correlation was found between the number of Formicinae and Myrmicinae species in the model area and the distance to the source of cement dust (respectively $\mathrm{r}=0.85$ and $\mathrm{r}=0.51$ at $\mathrm{p}<0.05$ ).

The basis of myrmecofauna are ants of the genus Lasius ( 2 species, $25 \%$ ), whose nests are marked in all areas (Fig. 1). The genus Formica is represented by 3 species (37.5\%), the genus Myrmica - 2 species $(25 \%)$, the genus Camponotus - 1 species (12.5\%). Ants M. rubra were observed in the village and in the control. In contrast, $M$. ruginodis was observed only in the meadow control. Anthills of $F$. polyctena are registered in meadows and forests control zone, as well as in the forest zone in the village. Representatives of the subgenus Formica s. p. in the area affected by cement dust was not found. The genus Camponotus is represented by one species of $C$. herculeanus, whose nests are found only in the village. Representatives of genera are unevenly distributed in the experimental plots: a total of 6 species of ants live in meadow plots, 4 of them in the village, 5 in the control; in deciduous forests - 7 species, including in the village - 5 species and its surroundings, 6 species of ants were noted (Table 1 ). 


\begin{tabular}{|lcccc|}
\hline Species $\backslash$ Territory & Meadow & Control meadow & Forest & Control forest \\
\hline $\begin{array}{l}\text { Camponotus } \\
\text { herculeanus }\end{array}$ & + & & + & \\
Myrmica rubra & + & + & + & + \\
M. ruginodis & & + & + & + \\
Formica polyctena & & + & & + \\
F. rufa & & & & + \\
F. fusca & + & + & + & + \\
Lasius niger & + & + & + & + \\
L. flavus & & + & & \\
\hline
\end{tabular}

Tab. 1. Species richness of ants in the research territory in the area of influence of the cement industry.

As a result of the analysis of the distribution of genera and species in the experimental meadows, we found a direct correlation between the number of ant species and the distance from the source of cement dust $(\mathrm{r}=0.87$ at $\mathrm{p}<0.05)$. The largest number of ant species in the affected area is observed from the genus Lasius (Fig. 2). Nests of the genus Myrmica occur no closer than $1 \mathrm{~km}$ from the cement plant, nests Formica - only in control.

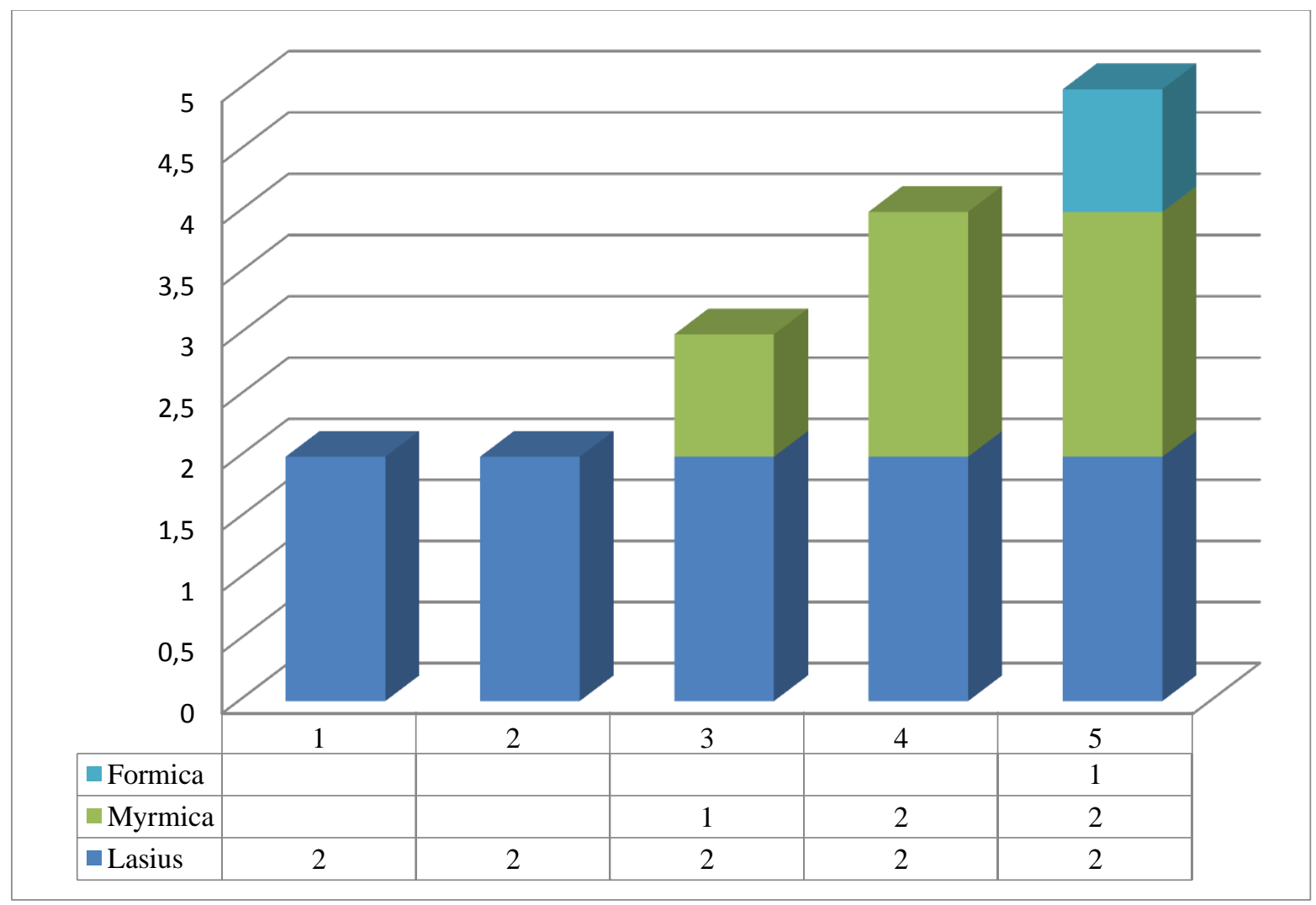

Fig. 2. Species richness of ants on meadows at different distances from the source of pollution. On the $X$ axis - the research area: 1 - 0; 2 - $0.5 \mathrm{~km} ; 3-1 \mathrm{~km} ; 4-5.5 \mathrm{~km} ; 5$ - control; along the B axis - the number of species.

A slightly different trend is observed in the analysis of species diversity of ants in meadows, which are located at different distances from the source of pollution. Species diversity of Lasius increases when approaching the source of pollution: the minimum value is noted in the control $(60 \%)$; near the source of dust - $100 \%$. For the genus Myrmica there is an inverse distribution: the maximum variety - 1 $\mathrm{km}$ from the cement plant (44.4\%), the minimum - in the control (20\%). The species diversity of Formica in the control is $20 \%$.

In general, deciduous forests are characterized by a high degree of similarity (Jacquard similarity index - 57.2): 4 common species were found (M. rubra, F. polyctena, L. flavus, L. niger). The nests of ants 
of the genus Camponotus under the influence of cement dust are registered only in the deciduous forest in the village. Ants of the subgenus Serviformica were noted only in the control. Nests of the subgenus Formica s. p. marked on both model sites.

In the deciduous forest, which is exposed to anthropogenic influence, nests of four genera of ants are marked, in the control - three. Ants of the genus Camponotus are registered only in the village (species diversity 20\%). The species diversity of Formica is higher in control (50\%) compared to the village $(20 \%)$, for the genera Myrmica and Lasius the species diversity in the zone of influence of cement dust and in the relatively clean zone is constant.

\subsection{THE DENSITY OF ANT NESTS}

Under the influence of cement dust on biotopes ants show an maladaptive reaction. The density of their settlements is maximum in the control areas (meadows $4.2 \pm 0.01 \mathrm{n} . / 25 \mathrm{~m}^{2}$; forest $3.2 \pm 0.01 \mathrm{n} . / 25$ $\mathrm{m}^{2}$ ) and decreases with the approach to the source of pollution. The minimum density of nests was registered in the most polluted areas (meadows $1.35 \pm 0.05 \mathrm{n} . / 25 \mathrm{~m}^{2}$; forest $2.3 \pm 0.15 \mathrm{n} . / 25 \mathrm{~m}^{2}$ ). The analysis of changes in the density of settlements of individual genera showed that in meadows located near the source of cement dust, the density of nests of all genera is minimal (Fig. 3).

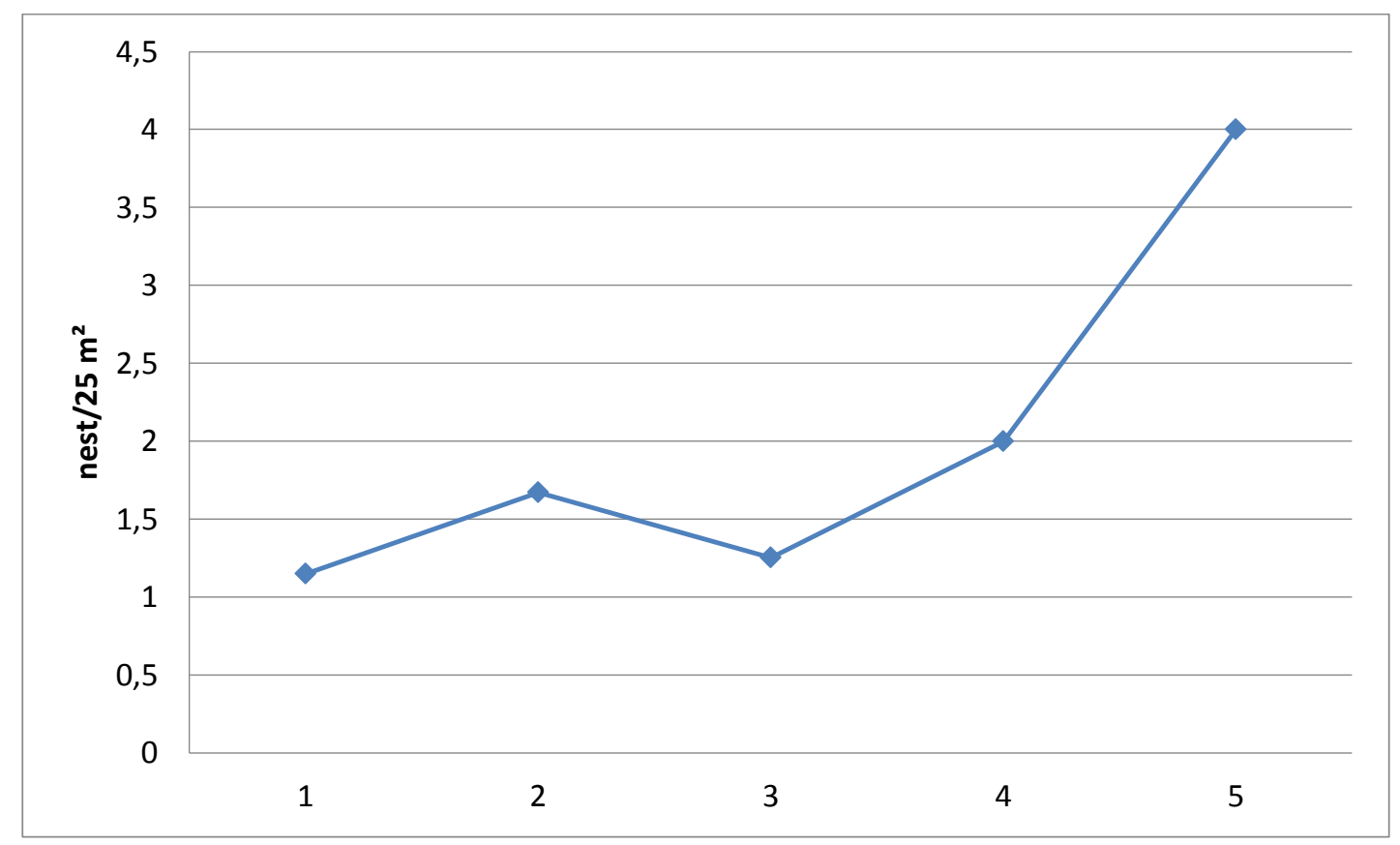

Fig. 3. The average density of ants nests on meadows, which are located at different distances from the source of cement dust. On the X axis - the research area: 1 - 0; 2 - $0.5 \mathrm{~km} ; 3$ - $1 \mathrm{~km} ; 4$ - $5.5 \mathrm{~km} ; 5$ - control.

With the distance from the source of pollution, the density of ant settlements increases significantly $(\mathrm{r}=0.97$ at $\mathrm{p}<0.05)$. Settlements of the genus Lasius near the cement plant are $1.4 \mathrm{n} . / 25 \mathrm{~m}^{2}$, in $5.5 \mathrm{~km}$ $2.1 \mathrm{n} . / 25 \mathrm{~m}^{2}$, in the control - reach the maximum values $-3.8 \mathrm{n} . / 25 \mathrm{~m}^{2}$. The same trend was found for ants of the genus Myrmica: $1 \mathrm{~km}$ from the plant, the density of their nests is $0.1 \mathrm{n} . / 25 \mathrm{~m}^{2}$, in the control $0.4 \mathrm{n} . / 25 \mathrm{~m}^{2}$. Settlement of ants of the genus Formica ( $F$. fusca) is registered only in the control, the density of settlements reaches $1.5 \pm 1.1 \mathrm{n} . / 25 \mathrm{~m}^{2}$.

Somewhat different trends were observed in the analysis of ant population density in deciduous forests. The density of ants nests of the genus Lasius is 1.8 times higher in control $\left(3.1 \mathrm{n} . / 25 \mathrm{~m}^{2}\right)$ than in the village $\left(1.75 \mathrm{n} . / 25 \mathrm{~m}^{2}\right)$. For other genera (Camponotus, Myrmica and Formica) the opposite reaction was registered. However, the density of anthills of $F$. fusca, which occur only in the control, reaches 2.5 $\pm 1.1 \mathrm{n} . / 25 \mathrm{~m}^{2}$. 


\subsection{NESTS TYPES}

Four types of nests were found in the experimental area: underground, domed, in the form of earthen and plant mounds, in wood. Analysis of the distribution of nest types in the area of influence of the cement plant revealed correlations of the number of predominant nest types from the distance to the source of cement dust (Fig. 4).

With a decrease in the degree of contamination, the share of underground nests increases $(r=0.90$ at $p<0.05)$, the share of dome nests decreases $(r=-0.94$ at $p<0.05)$. At the same time the sizes of a dome on the average decrease at distance from a pollution source. All nests registered in the most contaminated area consist of a mixture of cement dust and earth up to $45 \mathrm{~cm}$ in height. About $75 \%$ of all nests found were heavily overgrown. When excavating the nests are opened in layers, the dome was as if cemented.

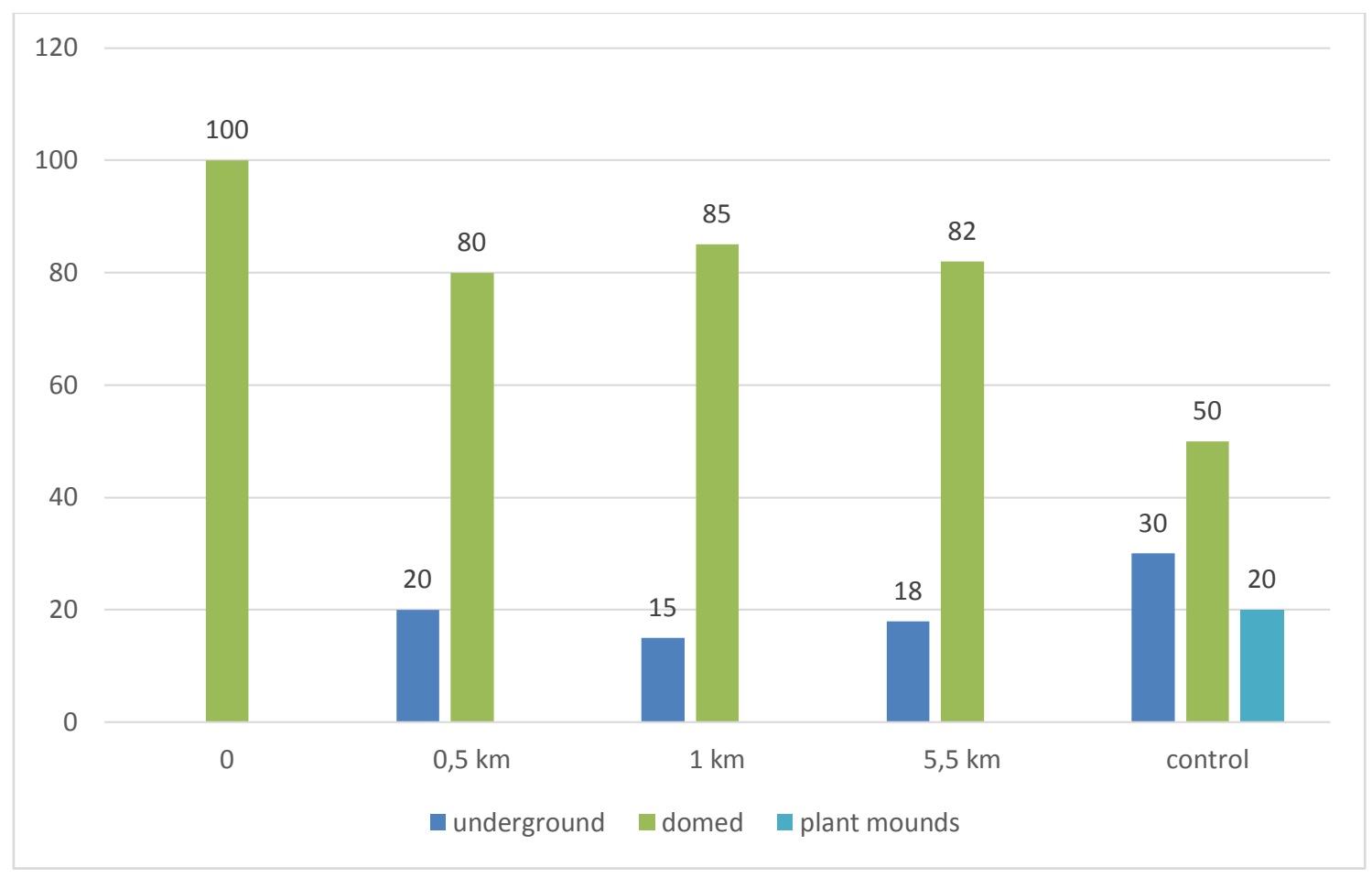

Fig. 4. Types distribution of ants' nests on meadows at different distances to the source of cement dust, \%.

Adaptation of ants to the influence of the cement plant differs from other types of influence and is expressed in the fact that in man-made areas the nests are more dome-shaped, smaller in diameter and much higher nests than those located in the control zone. This is due to the fact that the soil near the cement plant is covered with a layer of lime dust, reaching $5 \mathrm{~cm}$.

Most of the registered ant settlements in the control zone are represented by nests with earthen mounds or with mounds of plant remains. The average height of the dome nests reaches $45 \mathrm{~cm}$ with a shaft diameter of about $58 \mathrm{~cm}$.

The number of nests in the wood depends only on the number of felled trees in the study area and was observed only in the area of "Forest Control".

\section{CONCLUSION}

The density of ants' nests of the genus Formica is greatly reduced and they are replaced by ants of the genera Lasius and Myrmica under any type of anthropogenic impact, namely the impact of emissions from PJSC "Ivano-Frankivskcement". The height of the L. niger mound is inversely proportional to the distance to the source of industrial emissions, and the frequency of underground nests of ants of most species is directly proportional to the degree of anthropogenic impact. 


\section{REFERENCES}

[1] Bugrova N.M. Assessment of resistance to the recreational impact of various species of ants. Problems of the stability of biological systems. Kharkiv, 1990.

[2] Bugrova N.M. The influence of recreation on red forest ants in the forest park zone of the Novosibirsk Academgorodok. Ants and forest protection. Novosibirsk, 1987.

[3] Dlusskyi G.M. Methods for quantifying soil ants. Zoological journal, 44 (5) (1965), 716-727.

[4] Zaiceva I.F. The influence of the anthropogenic factor on the formation of the beetle (Heteroptera) fauna of urban plantations in Georgia. Achievements of entomologists in the USSR: ecology and faunistics, small groups of insects. Science, St. Petersburg, 1993.

[5] Mykytyn T.V. Anthropogenic impact on the myrmecofauna of technogenic-transformed neighborhoods of OJSC "Petrochemical of Prykarpattia". Visnyk of Cherkasy University. Biological Sciences Series, 36 (329) (2014), 67-74.

[6] Permitin D.V., Iliashenko V.B. Mathematical methods of zoological data processing. Kuzbassvuzizdat, Kemerovo, 1996.

[7] Pissarskiy B. Fauna of invertebrate urban areas of Warsaw. Bioindication in cities and suburbs. Moscow, 1993.

[8] Sergeev M.V., Dubatolov V.V. Peculiarities of the communities of butterflies (Lepidoptera, Rhopalocera) in a diffuse-type city (by the example of the Novosibirsk Academgorodok). Landscape ecology of insects. Science, Novosibirsk, 1988.

[9] Syvorov A.A. Ants under recreational stress. Soil fauna and soil fertility. Moscow, 1987.

[10] Uspenskiy K.V. System of forest pathological monitoring of oak forests of the Voronezh green zone. Moscow, 1999.

[11] Fedorova V.G. The impact of industrial emissions from the Novgorod chemical plant (Akront JSC) on the fauna and the number of insects. Problems of entomology in Russia. St. Petersburg, 1998.

[12] Chalidov A.B., Nikitin I.Yu. Influence of environmental pollution by industrial emissions on insects in forests. Monitoring system for forest protection. Krasnoiarsk, 1985.

[13] Bengtsson G., Rundgren S. Ground-living inverterbrates in metal-polluted forest soils. AMBIO: $j$. of the Human Environ., 13 (1) (1984), 29-33.

[14] Petal J. M. Adaptation of ants to industrial pollution. Mem. zool., 29 (1978), 99-108.

[15] Petal J. M. The effect of industrial pollution of Silesia on population of ants. Pol. Ecol. Stud. (PRL), 6 (4) (1980), 665-672.

[16] Pisarski B., Czechowski W. Influence de la pression urbaine sur la myrmecofauna. Mem. zool., 29 (1978), 109-128.

[17] Stary P., Kubiznakova J. Content and transfer of heavy metall air pollutants in populations of Formica spp. wood ants (Hymenoptera, Formicidae). Z. angew. Entomol., 104 (1) (1987), 1-10.

Address: Tetiana Mykytyn, Nelia Dolynko, Natalia Bielova, Vasyl Stefanyk Precarpathian National University, 57 Shevchenko St., Ivano-Frankivsk 76018, Ukraine;

Vasyl Stefurak, Ivano-Frankivsk National Medical University, 2 Halytska St., Ivano-Frankivsk 76018, Ukraine;

Vasyl Kuzenko, Regional Museum of Local lore, 4A Halytska St., Ivano-Frankivsk 76018, Ukraine.

E-mail: tetiana.mykytyn@pnu.edu.ua; dolynko.nelja@gmail.com; vasylstefurak@gmail.com; natalja14belowa@gmail.com; vasyl.kuzenko@gmail.com.

Received: 17.11.2020; revised: 15.12.2020. 
Микитин Тетяна, Долинко Неля, Стефурак Василь, Бєлова Наталя, Кузенко Василь. Вплив цементного пилу на угруповання мурашок (Нуmеnoptera, Formicidae). Журнал Прикарпатського університету імені Василя Стефаника, 7 (4) (2020), 19-26.

Проведено дослідження впливу цементного пилу в зоні ПАТ «Івано-Франківськцемент» на угруповання мурашок. В ході дослідження помітили, що при антропогенному навантаженні зникають мурашки роду Formica, які замінюються видами родів Lasius та Myrmica.

Аналізуючи розподіл родів та видів мурах на дослідних иуках нами виявлено пряму кореляційну залежність між числом видів мурах і відстанню від джерела цементного пилу ( $\mathrm{r}=0,87$ при p<0,05). Найбільша кількість видів мурах в зоні впдиву спостерігається з роду Lasius. Гнізда роду Myrmica трапляються не ближче 1 км від цементного заводу, гнізда Formica - тільки в контролі.

При дії цементного пилу на біотопи мурахи проявляють неадаптивну реакцію. Проведений аналіз зміни щільності поселення окремих родів показав, що на луках, розташованих поблизу джерел цементного пилу, щільність гнізд усіх родів мінімальна. 3 віддаленням від джерела забруднення щільність поселень достовірно зростае ( $\mathrm{r}=0,97$ при $\mathrm{p}<0,05)$. Поселення роду Formica (F. fusca)

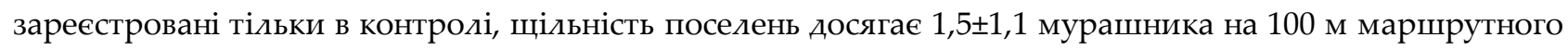
обліку. Щодо лісових біотопів, то щільність гнізд роду Lasius вища в контролі в 1,8 рази (3,1 гн./25 м²), ніж у селі (1,75 гн./25 м²). Для інших родів (Camponotus, Myrmica і Formica) зареєстрована протилежна

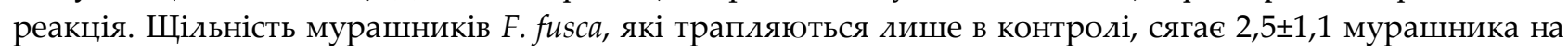
100 м маршрутного обліку.

Із зменшенням ступеня забруднення частка підземних гнізд збільшується ( $\mathrm{r}=0,90$ при $\mathrm{p}<0,05)$, частка купольних гнізд зменшується $(\mathrm{r}=-0,94$ при $\mathrm{p}<0,05)$. При цьому розміри купола в середньому зменшуються при віддаленні від джерела забруднення. Всі гнізда, зареєстровані в найбільш забрудненій зоні, складаються з суміші цементного пилу і землі висотою до 45 см. Близько 75 \% всіх знайдених гнізд були сильно зарослими. При розкопуванні гнізда купод був ніби зацементований.

Адаптація мурах до впливу цементного пилу відрізняється від інших видів впливу i виражається в тому, що на техногенних територіях гнізда мають частіше куполоподібну форму, менший діаметр і значно вищі гнізда, ніж ті, які розташовані у контрольній зоні. Це пояснюеться тим, що грунт поблизу цементного заводу покритий шаром вапняного пилу, що досягає 5 см.

Lasius niger є стійким до різних форм антропогенного впдиву, що можна пояснити пристосувальними особливостями форм мурашиного гнізда.

Кдючові слова: мурашки, антропогенний вплив, цементний пил, Lasius, Myrmica.
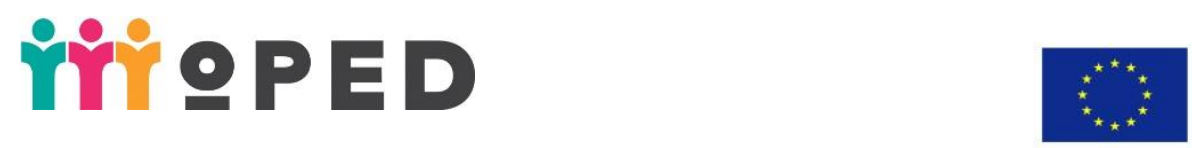

Co-funded by the Erasmus+ Programme of the European Union

"The article has been prepared in the framework of the Erasmus+ project "MoPED - Modernization of Pedagogical Higher Education by Innovative Teaching Instruments", No. 586098-EPP-1-2017-1-UAEPPKA2-CBHE-JP. This project has been funded with support from the European Commission. This publication reflects the views only of the author, and the Commission cannot be held responsible for any use which may be made of the information contained therein". 